\title{
Genetic and Antigenic Variability of HIV Type 1 in Brazil
}

\author{
JOSÉ C. COUTO-FERNANDEZ, ${ }^{1}$ WOUTER JANSSENS, ${ }^{2}$ LEO HEYNDRICKX,${ }^{2}$ JAN MOTTE, ${ }^{2}$ \\ KATRIEN FRANSEN, ${ }^{2}$ MARTINE PEETERS, ${ }^{2}$ ERIC DELAPORTE, ${ }^{3}$ BERNARDO GALVÃO-CASTRO, ${ }^{1}$ \\ PETER PIOT, ${ }^{2}$ and GUIDO VAN DER GROEN ${ }^{2}$
}

\begin{abstract}
Six Brazilian strains of human immunodeficiency virus type 1 (HIV-1) were isolated from infected individuals residing in different regions of Brazil between 1987 and 1989. Phylogenetic analysis based on an 860-base pair $e n v$ fragment, including V3, V4, V5, and the beginning of gp41, classified the Brazilian strains significantly in genotype B, with interhost distances between 5.9 and $13.1 \%$ (mean value, 10\%). Amino acid sequence analysis of the V3 loop revealed that three strains contained the North American/European GPGR motif as the tip of the loop whereas in the other three strains proline (P) was substituted by tryptophan $(\mathrm{W})$, methionine $(\mathrm{M})$, or phenylalanine (F). A consensus peptide, Bra-cons, was designed containing GWGR as the tip of the loop. Serological reactivity to the Bra-cons peptide and other V3 peptides (MN, SF2, HBX2, RF, MAL, ELI, Z6, and a Côte d'Ivoire peptide, CI-cons) was compared for 114 HIV-1-positive sera from Rio de Janeiro. Sixty-nine sera $(60.5 \%)$ reacted with peptides belonging to genotype $B$, of which 10 sera also reacted with peptides belonging to genotype $A(n=7)$ and $D(n=3)$. Eighteen sera $(15.8 \%)$ had binding antibodies to the Bra-cons peptide. A high number of sera $(n=43 ; 37.7 \%)$ had no antibodies to any of the $V 3$ peptides tested. This result suggests that HIV-1 variants with aberrant V3 loops may circulate in Rio de Janeiro.
\end{abstract}

\section{INTRODUCTION}

$\mathbf{T}_{8}$ HE ENVELOPE (Env) of HIV-1 contains highly variable regions. In the third variable region (V3) of the env gene, there are important determinants for virus neutralization, ${ }^{1,2}$ cell tropism, ${ }^{3,4}$ and viral infectivity. ${ }^{5}$ However, the role of distinct HIV variants in the development of AIDS is unclear. On the basis of the induction of neutralizing antibodies in experimental animals, this viral epitope is under investigation as a candidate for potential HIV-1 vaccines and as a target for immunoprophylaxis strategies. ${ }^{6}$ However, to protect against HIV infection it is important that vaccines should induce a protective immune response against a wide range of viruses, especially those most common within the community to be protected.

Brazil is one of the countries most affected by HIV-1. In November 1993, a cumulative total of 43,964 AIDS cases had been reported by the Ministry of Health for all 27 states. $^{7}$

Data regarding HIV-1 diversity in Brazil has already established that subtype B viruses (some with unusual V3 sequences) are prevalent, with a smaller apparent proportion of subtype $F$ viruses. ${ }^{8-13}$
The aim of the study was to analyze the genetic variability in the env gene of HIV-1 strains isolated from patients from different geographic regions in Brazil. Furthermore, we investigated the seroreactivity of $114 \mathrm{HIV}-1$ Western blot-confirmed seropositive Brazilian individuals to peptides mimicking the principal neutralizing domain (PND) of the V3 loop of HIV-1 strains belonging to different genotypes as well as to a consensus PND peptide of Brazilian isolates.

\section{MATERIALS AND METHODS}

\section{Subjects}

HIV-1 strains of six HIV-1-infected individuals residing in different regions in Brazil and attending public hospitals during the time period between 1987 and 1989 were included in this study. The $\mathrm{CD}^{+}$cell counts $\left(\times 10^{6} /\right.$ liter $)$, the most widely used marker for staging of asymptomatic HIV infection, ${ }^{14}$ are indicated: P3 (CD4 < 200), São Paulo; P4 (200< CD4 < 500), P6 $(200<$ CD4 < 500), and P7 (CD4 > 500), Bahia; P8 $(200<$ CD4

\footnotetext{
'Advanced Public Health Laboratory, Centro de Pesquisas Gonçalo, Fundação Oswaldo Cruz, Bahia CEP 41-945, Brazil.

${ }^{2}$ Division of Microbiology, Department of Infection and Immunity, Institute of Tropical Medicine, 2000 Antwerp, Belgium.

${ }^{3}$ INSERM U13/MMEA-Hôpital Bichat-Claude Bernard, Paris, France.
} 


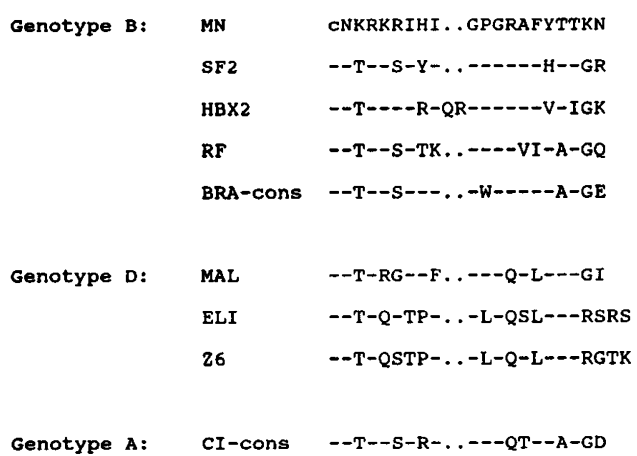

FIG. 1. Alignment of V3 peptides. Genotype classification of the V3 peptides is according to the classification of the respective strains, from which they are derived. ${ }^{16}$ Amino acid identity between sequences is represented by dashes; points are introduced to align the sequences.

$<500$ ), Paraná; P9 (CD4 < 200), Rio de Janeiro. From these individuals the corresponding serum was not available. Additionally, HIV-1-positive sera were obtained from 114, mostly asymptomatic, individuals from Rio de Janeiro, Brazil. HIV-1 positivity was confirmed by Western blot (WB-1; Diagnostic Biotechnology, Heverlee, Belgium), using the World Health Organization (WHO) criteria. ${ }^{15}$ To analyze the specificity of antibody reaction to a consensus PND peptide of Brazilian isolates, HIV-1-positive sera from individuals (asymptomatic or having AIDS) were included from Belgium $(n=139)$, Rwanda $(n=207)$, Gabon $(n=90)$, and Kenya $(n=$ $60)$.

\section{Peptides}

The V3 synthetic peptides were 20 to 22 amino acids long and contained a cysteine residue at the amino terminus for binding purposes in the enzyme-linked immunosorbent assay (ELISA). The peptides cover the PND and are derived from sequences from genotype A (CI-cons: Côte d'Ivoire), genotype B (MN, SF2, and HBX2, North America; RF, Haiti; Bra-cons, Brazil) and genotype D (ELI, Z6, and MAL, Zaire). Genotype classification was according to Myers et al. ${ }^{16}$ The alignment of the V3 peptides is shown in Fig. 1. Amino acid numbering is according to the MN strain. ${ }^{16}$ The peptides were synthesized at Neosystems (Strasbourg, France). The CI-cons peptide was designed on the most common V3 sequences of Côte d'Ivoire strains as previously described. ${ }^{17}$ The Bra-cons peptide was designed on V3 loop sequences of this study and sequences from HIV-1 strains from Bahia and São Paulo ${ }^{9}$ and Rio de Janeiro. ${ }^{10,11} \mathrm{~A}$ consensus sequence was derived in which proline $(P)$ in the central GPGR motif was exchanged for tryptophan (W), resulting in the peptide cNTRKSIHIGWGRAFYATGE.

\section{Peptide assay}

An ELISA was used to monitor antibody reactivity to the V3 loop peptides. Stock solutions $(1 \mathrm{mg} / \mathrm{ml})$ of these peptides were reconstituted in $0.05 \mathrm{M}$ carbonate buffer ( $\mathrm{pH} \mathrm{9.6)}$ ) and stored at $-20^{\circ} \mathrm{C}$. Peptides, at a concentration of $100 \mathrm{ng} / 200 \mu \mathrm{l}$ of carbon- ate buffer, were coated overnight at room temperature in microtiter plates (Immunoplate; Nunc, Roskilde, Denmark). The plates were washed twice with phosphate-buffered saline (PBS) $-0.01 \%$ merthiolate- $0.05 \%$ Tween 20 . Nonspecific binding sites were blocked with blocking buffer (PBS-0.05\% Tween $20-2 \%$ bovine serum albumin) at $37^{\circ} \mathrm{C}$ for $2 \mathrm{hr}$. Of serum dilutions, made in blocking buffer, $200 \mu \mathrm{l}$ was incubated with the immobilized peptides for $1 \mathrm{hr}$ at $37^{\circ} \mathrm{C}$. The plates were washed and incubated with blocking buffer containing antihuman IgG-peroxidase conjugate, diluted 1:30,000, for $1 \mathrm{hr}$ at $37^{\circ} \mathrm{C}$. The plates were washed and antibody binding was visualized by adding substrate buffer $(8.7 \mathrm{mg}$ of tetramethylbenzidine/ml dimethyl sulfoxide [DMSO] diluted $1: 100$ in $0.1 \mathrm{M}$ citrate phosphate buffer, $\mathrm{pH} 4.3$, and $0.006 \% \mathrm{H}_{2} \mathrm{O}_{2}$ ). After $30 \mathrm{~min}$ the reaction was stopped by adding $50 \mu \mathrm{l}$ of $4 \mathrm{~N} \mathrm{H}_{2} \mathrm{SO}_{4}$. The optical density was read at $450 \mathrm{~nm}$. Ten HIV-1-negative sera were used to establish the cutoff value-of each assay as the mean value plus 3 standard deviations. Antibody reaction to a peptide was scored positive if the optical density (OD) value was above the cutoff value. Cutoff values ranged from 0.1 to 0.5 . For uniformity and to eliminate nonspecific reactivity the highest cutoff value $(0.5)$ was used for all the assays.

\section{Virus isolation and DNA preparation}

HIV-1 isolation was carried out according to Barré-Sinoussi et al. ${ }^{18}$ Briefly, $2 \times 10^{6}$ periferal blood mononuclear cells (PBMCs) from HIV-1-seropositive individuals were separated on a Ficoll-Hypaque gradient and cocultivated with $5 \times 10^{6}$ phytohemagglutinin (PHA)-stimulated donor PBMCs. The cultures were maintained in RPMI-1640 medium supplemented with $20 \%$ heat-inactivated fetal bovine serum and recombinant interleukin $2(50 \mathrm{U} / \mathrm{ml})$ (Innogenetics, Zwijnaarde, Belgium). Cultures were expanded to $2.5 \times 10^{7}$ cells by adding $2 \times 10^{6}$ PHA-stimulated donor PBMCs every 3 to 4 days over a 2- to 3 week period. Viral growth was determined by monitoring viral antigens by an HIV antigen capture enzyme immunoassay (EIA; Innogenetics). HIV-containing supernatants were kept at $-70^{\circ} \mathrm{C}$ until use. Frozen infected cells were thawed and resuspended in $1 \mathrm{ml}$ of TE buffer ( $10 \mathrm{mM}$ Tris- $\mathrm{HCl}$ [pH 7.5]-1 mM ethylenediaminetetraacetic acid [EDTA]) and treated with $0.5 \%$ sodium dodecyl sulfate (SDS) and proteinase $\mathrm{K}$ (20 $\mu \mathrm{g} / \mathrm{ml}$ ) at $37^{\circ} \mathrm{C}$ overnight. Nucleic acids were extracted by phenol-chloroform, ${ }^{19}$ precipitated in absolute ethanol, and resuspended in $100 \mu \mathrm{l}$ of $\mathrm{H}_{2} \mathrm{O}$. The quantity of total DNA was measured by optical density and their concentration adjusted to a final concentration of $0.1 \mu \mathrm{g} / \mathrm{ml}$.

\section{Polymerase Chain Reaction, cloning, and sequencing}

The polymerase chain reaction (PCR) conditions and primers were as described previously. ${ }^{17}$ Primer H1E101 was biotinylated for direct sequencing purposes. An approximately 860-base pair (bp) fragment containing V3, V4, V5, and the beginning of gp41 was amplified for the six Brazilian strains. Nested PCR fragments were purified with Dynabeads (Medichim, Heppignies, Belgium) and directly sequenced using the direct solid-phase sequencing approach. ${ }^{20}$ For one isolate (P6) it was not possible to obtain a satisfactory nested PCR product. This fragment was cloned in a pUC18 cloning vector. Sequence reactions were performed using the AutoRead se- 
quencing kit and fluorescein-labeled primers (Pharmacia Biotech, Roosendaal, the Netherlands). Electrophoresis and data collection were done on an ALF automatic sequencer (Pharmacia Biotech).

\section{Sequence data analysis}

The six HIV-1 env Brazilian sequences were aligned with 19 previously known sequences of HIV-1 isolates of diverse geographical origin. Starting from the alignment, a distance matrix, corrected for multiple mutations per site according to Jukes and Cantor, ${ }^{21}$ was constructed. ${ }^{22}$ Tree topologies were inferred by neighbor joining, ${ }^{23}$ one of the most effective tree construction methods available at this time. ${ }^{24,25}$ Tree construction and bootstrap analysis were realized with the software package TREECON. ${ }^{26}$

The nucleotide sequence data were deposited in the EMBL, GenBank, and DDBJ nucleotide Sequence Database under the following accession numbers: X78512-X78517.

\section{RESULTS}

\section{Phylogenetic analysis}

The Brazilian sequences were compared phylogenetically with the 860-bp env fragment of 19 previously published sequences representative of 6 different genotypes: 4 strains of genotype A (Z321 [Zaire], D687 [Ghana], SF170 [Rwanda], and U455 [Uganda]), 5 strains of genotype B (OYI [Gabon], LAI [France], RF [Haiti], and MN and SF2 [United States]), 2 strains of genotype C (NOF [South Africa] and D747 [India]), 4 strains of genotype D (NDK, JY1, Z2Z6, and ELI [Zaire]), 2 strains from genotype E (CM235 and CM239), ${ }^{27}$ and 2 strains from genotype $\mathrm{F}$ (BZ126 and BZ163). ${ }^{13} \mathrm{SIV}_{\mathrm{cpz}=\mathrm{gab}}$ was included as outgroup sequence.

In the phylogenetic tree (Fig. 2), six branches representing six different genotypes (A, B, C, D, E, and F) are supported significantly by bootstrap analysis. All Brazilian isolates in this study are situated in genotype B, supported by $100 \%$ of the bootstrap trees. The interhost differences at nucleotide level for Brazilian strains were $5.9 \%$ (between P3 and P6) to $13.1 \%$ (between P8 and P9). The mean value for interhost difference was $10 \%$.

\section{Genetic analysis of the V3 region}

V3 amino acid sequences from Brazilian isolates were compared with the V3 consensus sequence of genotype B (Fig. 3). ${ }^{16}$ The amino acid sequences around the V3 loop apices were similar to those of some North American and European isolates. The central GPGR tetrapeptide was found in three of six Brazilian strains. In the other three samples (P3, P6, and P8), proline $(\mathrm{P})$ in the crown of the loop was replaced by tryptophan $(\mathrm{W})$, methionine $(\mathrm{M})$, and phenylalanine $(\mathrm{F})$, respectively.

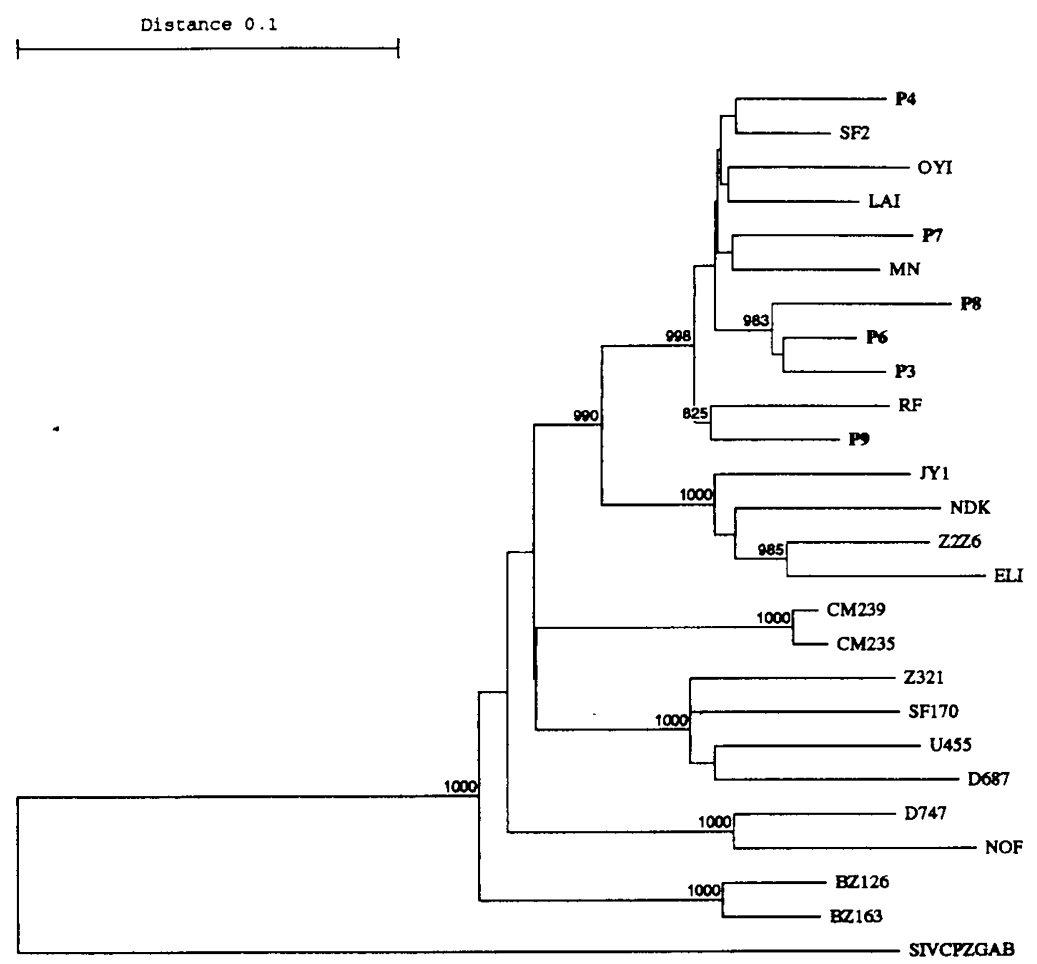

FIG. 2. Phylogenetic tree based on 853 unambiguously aligned positions of HIV-1 sequences from 25 different patients. The sequences determined in this study are indicated in bold. The root of the tree is placed such as to equalize its distance to the outgroup sequence $\mathrm{SIV}_{\mathrm{cpz}-\mathrm{gab}}$ and its average to the HIV-1 sequences. The distance between two sequences is obtained by summing the lengths of the connecting horizontal branches, using the scale on top. The number of bootstrap trees out of 1000 replications supporting a particular phylogenetic group in more than $50 \%$ is placed alongside the node considered. 


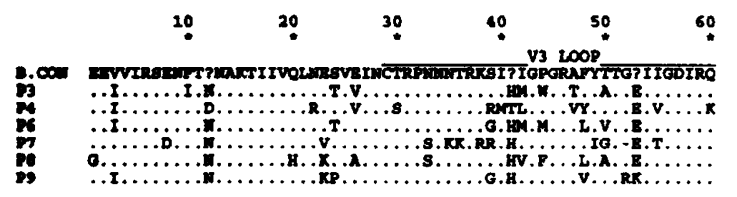

$70 \quad 60 \quad 90 \quad 100 \quad 110.120$

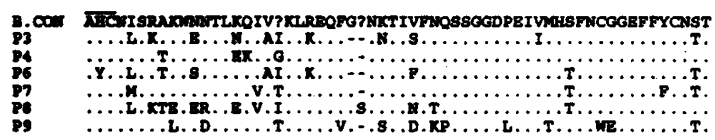

$130 \quad 140 \quad 150 \quad 260 \quad 170 \quad 180$

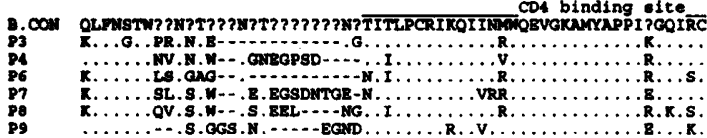

$190 \quad 200 \quad 210 \quad 220.230 .240$

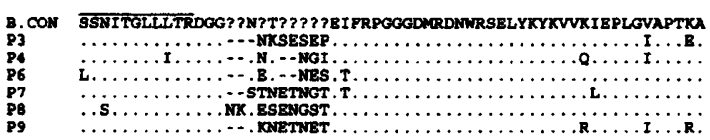

$250 \quad 260270 \quad 280.290$

$9 P 20-V /-9 P 41$

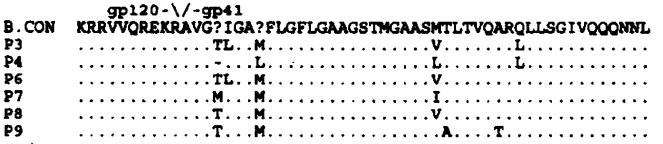

FIG. 3. Amino acid sequence alignment of part of the envelope glycoprotein, including V3, V4, V5, and the beginning of gp41 of six Brazilian strains. The database consensus sequence for genotype B, according to Myers et al., ${ }^{16}$ is on top. Amino acid identity between sequences is represented by points; dashes are introduced to align the sequences; the overbars are indicative for the V3 loop region and the CD4 binding site as indicated between them.
Antibody reactivity of sera from HIV-seropositive Brazilian individuals against V3 loop peptides in ELISA

Eighteen different seroreactivity patterns have been observed among the 114 Brazilian HIV-1-positive sera when tested in ELISA on 9 different V3 peptides (Fig. 4A). Of the 114 HIV-1-positive sera from Rio de Janeiro tested, $69(60.5 \%)$ reacted to 1 or more peptides mimicking V 3 loop sequences of HIV-1 strains classified in genotype B (Figs. 1 and 4A). Seven of these sera also reacted with the CI-cons peptide (genotype A); two sera also reacted with the Z6 peptide and one serum also reacted with the ELI and MAL peptides (genotype D). The number of sera having antibody reactivity to the RF and HBX2 peptides was $14(12.3 \%)$ and $8(7 \%)$, respectively. All sera reacting to the $\mathrm{RF}$ and/or the $\mathrm{HBX} 2$ peptide also reacted to the SF2 and MN peptides. All but one of the sera having antibodies to the SF2 peptide $(n=39)$ also reacted to the MN peptide $(n=$ $38)$. Of 18 sera (15.8\%) that reacted with the Bra-cons peptide, 2 did not cross-react with other V3 peptides. Three sera had serological reactivity to V3 peptides based on Zairean HIV-1 strains, classified in genotype D: two sera reacted with the Z6 peptide and one serum reacted with the ELI and MAL peptides.

Nine sera $(7.9 \%)$ had antibodies directed to the CI-cons peptide. Two of these sera did not react with other peptides. Fortythree sera $(37.7 \%)$ had no binding antibodies directed to epitopes on the V3 peptides used in this study (Fig. 4A). An increase in the cutoff value from $O D=0.5$ to $O D=1.0$ resulted in a decrease in the number of sera reacting with a certain V3 peptide in ELISA (Fig. 4B). The number of different seroreactivity patterns was now reduced to 12 . The percentage of sera having antibody reactivity to one or more V3 peptides decreased by $28 \%$ (from $n=71$ to $n=51$ ). All of them had antibodies to subtype $B$ peptides. The decrease in reactivity toward the different V3 peptides was as follows: $29 \%$ for the $\mathrm{MN}$ peptide (from $n=66$ to $n=47$ ), $36 \%$ for the SF2 peptide (from $n=$ 39 to $n=25$ ), $43 \%$ for the RF peptide (from $n=14$ to $n=8$ ),
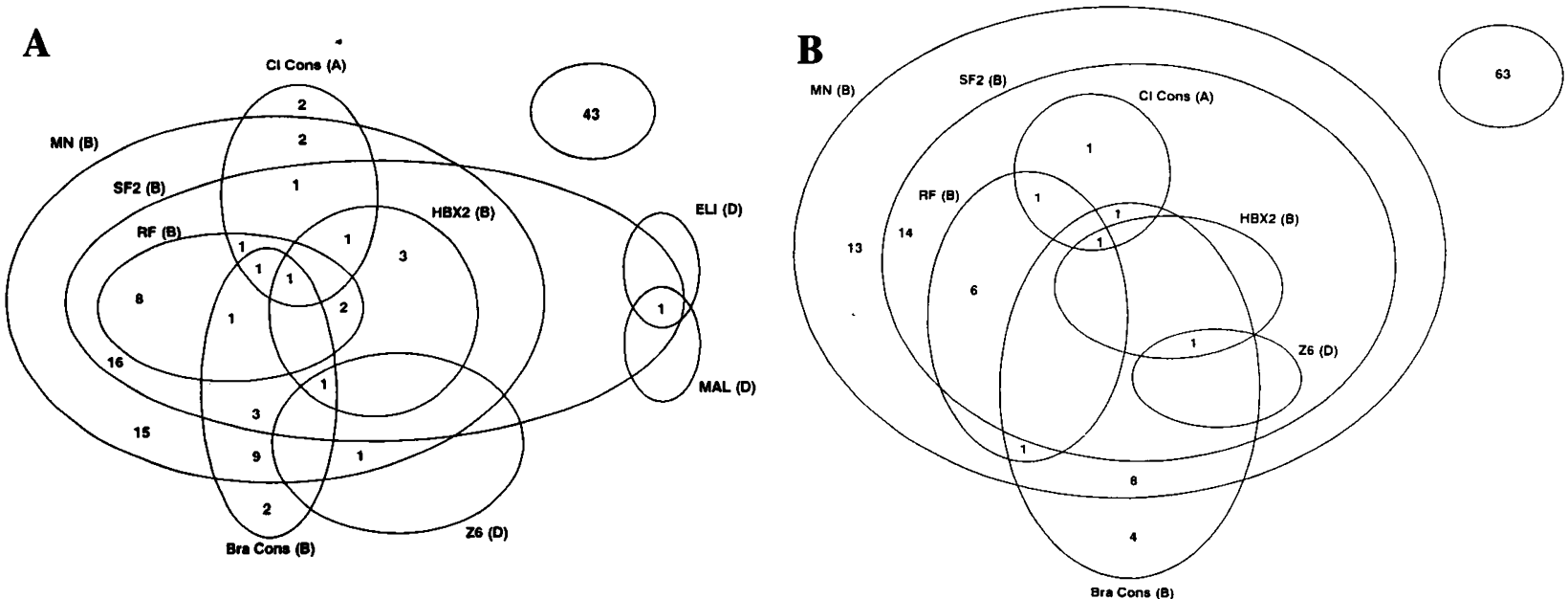

FIG. 4. Antibody reactivity of Brazilian sera to V3 loop peptides of HIV-1 isolates of different genotypes. The inside of each ellipse, indicated by a reference peptide, contains the number of sera reactive with this peptide. The genotypes of the strains from which the V3 loop peptides are derived are indicated in parentheses. A separate ellipse contains the number of sera having no binding antibodies to the $\mathrm{V} 3$ peptides tested. (A) Cutoff $\mathrm{OD}=0.5$; (B) cutoff $\mathrm{OD}=1.0$. 
$75 \%$ for the HBX2 peptide (from $n=8$ to $n=2$ ), $11 \%$ for the Bra-cons peptide (from $n=18$ to $n=16$ ), $55 \%$ for the CI-cons peptide (from $n=9$ to $n=4$ ), $50 \%$ for the Z6 peptide (from $n=$ 2 to $n=1$ ), and $100 \%$ for the ELI and MAL peptides (from $n=$ 1 to $n=0)$.

\section{Antibody reactivity to the Bra-cons peptide}

Antibody reaction to the Bra-cons peptide was studied for sera from Belgium $(n=139)$, Rwanda $(n=207)$, Gabon $(n=$ 90 ), and Kenya ( $n=60$ ), and compared to antibody reaction for sera from Brazil $(n=114)$. The percentage of sera from the different countries, scoring positive (OD $>0.5$ ) in the peptide assay, was $15.8 \%(n=18)$ for Brazil, $7.2 \%(n=10)$ for Belgium, $6.8 \%(n=14)$ for Rwanda, $4.4 \%(n=4)$ for Gabon, and $6.7 \%$ $(n=4)$ for Kenya. To determine the specificity of antibody reaction to the Bra-cons peptide, the OD values of the sera from the different countries reacting with this peptide were compared (Fig. 5). An increase in the cutoff value from $O D=0.5$ to $O D=$ 1.0 resulted in a decrease in the number of sera scoring positive in ELISA: in Brazil, $11 \%$ (from $n=18$ to $n=16$ ); in Belgium, $60 \%$ (from $n=10$ to $n=4$ ); in Rwanda, $64 \%$ (from $n=14$ to $n$ $=5$ ); in Gabon, $100 \%$ (from $n=4$ to $n=0$ ); and in Kenya, $100 \%$ (from $n=4$ to $n=0$ ).

\section{DISCUSSION}

Using the env fragment encoding V3, V4, V5, and the beginning of gp41, it is possible to generate phylogenetic trees that are statistically confident and that group HIV-1 strains into the same genotypes as documented by Myers et al., ${ }^{16}$ based on larger fragments or total genomes. ${ }^{17}$ All Brazilian strains in this study clustered in genotype B. The GPGR motif was present in $50 \%$ of the Brazilian strains (P4, P7, and P9). The Brazilian strains lacking GPGR had GWGR (P3, São Paulo), GMGR (P6, Bahia), and GFGR (P8, Paraná) instead. Globally, GPGR is found in B subtypes only $63 \%$ of the time. ${ }^{16}$ In the Centers for Disease Control (CDC, Atlanta, GA) study of a Florida dentist, out of 39 Florida control strains 12 did not have GPGR as the tip of the V3 loop. ${ }^{28}$ In a seroconverter study from the Netherlands, 11 of 75 strains were variable in GPGR. ${ }^{29}$ Finally, it is not uncommon to find intrapatient variation in this motif, which has implications for serological reactivity. ${ }^{30} \mathrm{~V} 3$ sequence data from HIV-1 strains circulating in Bahia and São Paulo, Brazil, were reported. ${ }^{11}$ Thirty-six percent $(n=8)$ of the strains had the GWGR tetrapeptide motif and were from individuals from Bahia. Also, V3 sequence data from HIV-1 strains circulating in Rio de Janeiro and São Paulo were reported. ${ }^{10}$ Fortythree percent $(n=12)$ of the strains had the GWGR tetrapeptide motif, GPGR was observed in only eight strains $(28.5 \%)$, and eight strains $(28.5 \%)$ presented a novel sequence. The GWGR tip of the loop has been found only in Brazil to date. It is a common form in Brazil, and its presence accounts for much of the decrease in frequency of GPGR forms in Brazil. Therefore the relative decrease in GPGR could be due to a founder effect with the GWGR form, and not to the excessive variation in this motif in Brazil. A study on 30 samples from patients of Argentina revealed only GPG as the tip of the V3 loop. ${ }^{31}$ This may be due to a recent introduction or to clustering of the samples in that study. The prevalence of HIV-1 strains having GWG, GMG, or GFG as the tip of the V3 loop, for other regions of Brazil and for other South American countries, remains unclear. Although the majority of Brazilian isolates belong to genotype $\mathrm{B}$, the presence of genotype $\mathrm{F}$ isolates has been demonstrated. ${ }^{11-13}$

The prevalence of antibodies binding with the Bra-cons peptide, having GWG as its central motif, was studied for $114 \mathrm{HIV}$ 1-positive Western blot-confirmed sera from Rio de Janeiro and compared with the seroreactivity to other peptides of HIV-1 strains from different geographic regions. Seventy-one sera

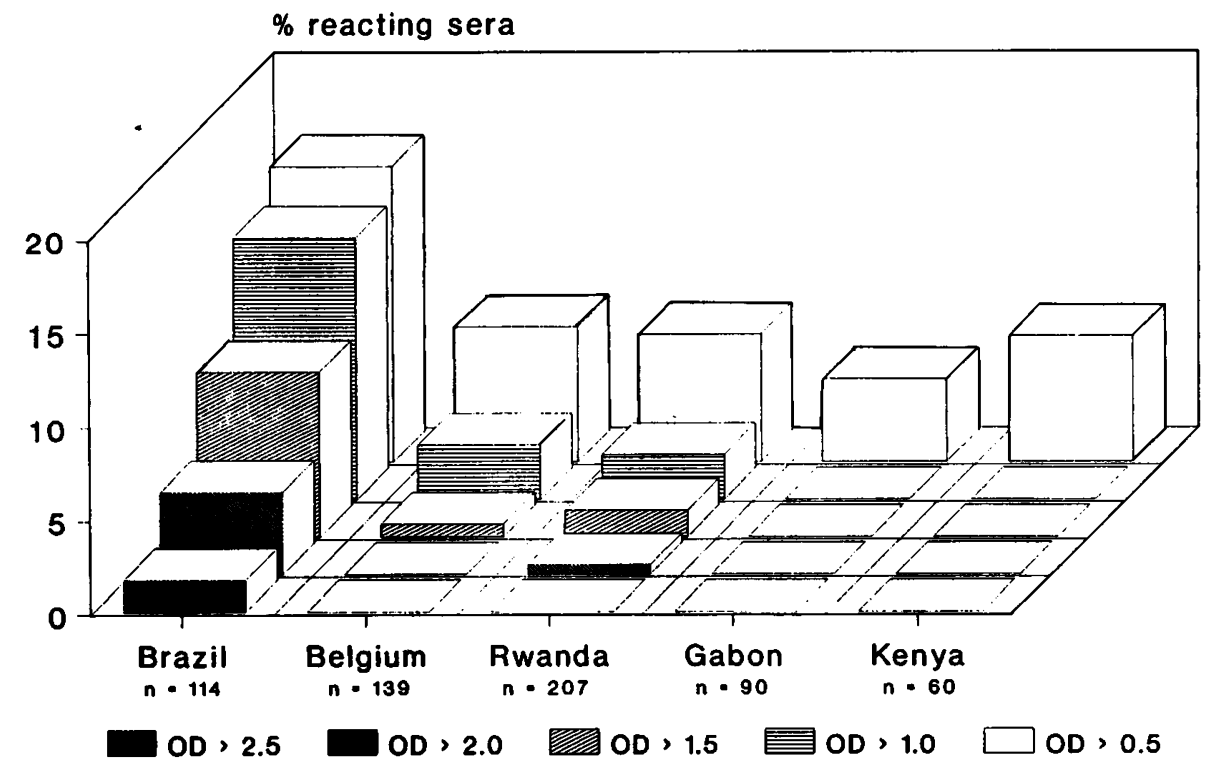

FIG. 5. Specificity of antibody reaction to the Bra-cons peptide. The percentage of sera of the different countries reacting with the Bra-cons peptide is indicated in order of increasing OD values. 
(62.3\%) had serological activity to one or more V3 peptides in this study. All except two had binding antibodies to V3 peptide(s) based on genotype $B$ sequences. This finding corresponds with the phylogenetic classification in genotype $B$ of the HIV-1 strains from Brazil in this and previous studies. ${ }^{9-12}$ However, a prevalence of $60 \%$ of MN V3 peptide-reactive Brazilian sera was low compared with the prevalence of $\mathrm{MN}$ V3 peptide-reactive sera observed in eight other countries, of which one was European and seven were African. This observation, together with the low number of sera reacting with peptides of genotype D strains, made Brazilian seropositive sera different in their V3 loop reactivity pattern (data not shown). Antibody reaction of Brazilian sera to the Bra-cons peptide was $15.8 \%$. Brazilian sera reacted with higher specificity to the Bracons peptide in comparison with sera from Belgium, Rwanda, Gabon, and Kenya (Fig. 5). Raising the cutoff value from $\mathrm{OD}=$ 0.5 up to $O D=1.0$ resulted in an increased specificity and eliminated some of the cross-reactivity against the Bra-cons peptide. This is reflected by an $11 \%$ (Brazil) versus a $60 \%$ (Belgium), $64 \%$ (Rwanda), and $100 \%$ (Gabon and Kenya) reduction in the number of sera reactive with the Bra-cons peptide, in solidphase ELISA. Antibody reaction of Brazilian sera to the CIcons peptide (genotype A) was low (7.9\%), compared to sera from seven African countries ranging from $70.7 \%$ (Gabon) to 94.7\% (Côte d'Ivoire) (data not shown). This may indicate a different evolution of HIV-1 strains in Africa and Brazil. Raising the cutoff value from $O D=0.5$ to $O D=1.0$ resulted in a decrease in Brazilian sera having antibodies to certain V3 peptides. The decrease was different for each V3 peptide analyzed. The lowest decrease was observed for reaction with the Bra-cons peptide $(11 \%)$. The decrease in reactivity to other genotype B-derived peptides was more profound: $\mathrm{MN}, 29 \%$; SF $2,36 \%$; RF, $43 \%$; and HBX2, $75 \%$.

The high number of sera $(n=43 ; 37.7 \%)$ having no binding antibodies to any of the V3 peptides tested may indicate the presence of V3 loop-aberrant HIV-1 strains in Brazil, as is partially confirmed by our results. Although the six Brazilian isolates all belong to clade $\mathrm{B}, 50 \%$ of them had a remarkable difference at the tip of the loop (P3 [GWGR], P6 [GMGR], and P8 [GFGR]). Perhaps some of the nonreacting sera could react with a subtype $\mathrm{F} V 3$ peptide containing a relatively distinctive LGPG $(Q / R)$. Also, the lack of reactivity of many of the sera could be due to positions proximal to the tip of the V3 loop. Serotyping using peptides corresponding to new variants may be important to trace the prevalence of these variants in the population. The PND present on the synthetic peptides contains a core tetrapeptide in a $\beta$-turn array ${ }^{32}$ that is as highly conserved as GPGR for North American/European strains and as GPGQ for African strains. ${ }^{33}$ However, the PND of Brazilian strains often shows substitution of proline (P) in the GPG motif to tryptophan $(\mathrm{W})$, methionine $(\mathrm{M})$, and phenylalanine $(\mathrm{F})$. This kind of substitution may result in an altered epitope eliciting antibodies with low or no binding affinity for V3 peptides having GPGR or GPGQ as the tip of the V3 loop. These data are indirect evidence for the circulation in Brazil of HIV strains with aberrant V3 loop amino acid sequences. Further work is necessary to characterize in further detail these unusual HIV-1 strains as well as to determine their prevalence among Brazilian HIVinfected individuals. The outcome of these studies may contribute to a more efficient design of an HIV vaccine in Brazil.

\section{ACKNOWLEDGMENTS}

The authors thank Betty Willems and Annemie Leonaers for technical assistance. They gratefully acknowledge the following people for providing sera for this study: Dr. B. Colebunders, Dr. M. Vandenbruaene, and Dr. J. Goeman (Belgium), Dr. J. Bogaerts (Rwanda), Dr. L. Perret (Gabon), and Dr. M. Temmerman (Kenya). This work was supported by grants (Nos. 3-3025-91 and F5/5/25-RN-N24) from the National Fonds voor Wetenschappelijk Onderzoek (Brussels) and was partially supported by the Brazilian National Research Council $\left(\mathrm{CNP}_{\mathrm{q}}\right.$ RHAE).

\section{REFERENCES}

1. Looney DJ, Fisher AG, Putney SD, Rusche JR, Redfield RR, Burke DS, Gallo RC, and Wong-Staal F: Type-restricted neutralization of molecular clones of human immunodeficiency virus. Science 1988;241:357-359.

2. Meloen RH, Liskamp RM, and Goudsmit J: Specificity and function of the individual amino acids of an important determinant of human immunodeficiency virus type 1 that induces neutralizing activity. J Gen Virol 1989;70:1505-1512.

3. Hwang SS, Boyle TJ, Lyerly HK, and Cullen BR: Identification of the envelope V3 loop as the primary determinant of cell tropism in HIV-1. Science 1991;253:71-74.

4. Westervelt P, Trowbridge DB, Epstein LG, Blumberg BM, Li Y, Hahn BH, Shaw GM, Price RW, and Ratner L: Macrophage tropism determinants of human immunodeficiency virus type 1 in vivo. J Virol 1992;66:2577-2582.

5. Ivanoff LA, Dubay JW, Morris JF, Roberts SJ, Gutshall L, Sternberg EJ, Hunter E, Matthews TJ, and Petteway SR Jr: V3 loop region of the HIV-1 gp120 envelope protein is essential for virus infectivity. Virology 1992;187:423-432.

6. Baltimore D and Feinberg MB: HIV revealed: Toward a natural history of the infection. N Engl J Med 1989;321:1673-1675.

7. Ministério de Saúde: AIDS Boletim Epidemiológico (Brasil). 1993;VI-10.

8. Couto-Fernandez JC, Morgado MG, Ivo-dos-Santos J, and GalvãoCastro B: Molecular and biological diversity of HIV-1 in Brazil. Mem Inst Oswaldo Cruz 1993;87:249-255.

9. Potts KE, Kalish ML, Lott T, Orloff G, Luo C-C, Bernard MA, Brites Alves C, Badaro R, Suleiman J, Ferreira O, Schochetman G, Johnson WD Jr, Ou C-Y, Ho JL, and the Brazilian AIDS Research Group: Genetic heterogeneity of the V3 region of the HIV-1 envelope glycoprotein in Brazil. AIDS 1993;7:1191-1197.

10. Morgado MG, Sabino E, Bongertz V, Brigido L, Galvão-Castro B, Hendry RM, and Mayer A: V3 sequence diversity among Brazilian HIV-1 samples. Abstracts IXth International Conference on AIDS, Berlin 1993; p. 4469. [Po-A 10-01698]

11. Morgado MG, Sabino E, Shpaer EG, Bongertz V, Brigido L, Guimarães MDC, Castilho EA, Galvão-Castro B, Mullins JI, Hendry RM, and Mayer A: V3 region polymorphisms in HIV-1 from Brazil: Prevalence of subtype B strains divergent from the North American/European prototype and detection of subtype F. AIDS Res Hum Retroviruses 1994;10:569-576.

12. Louwagie J, McCutchan FE, Peeters M, Brennan TP, SandersBuell E, Eddy AG, van der Groen G, Fransen K, Gershy-Damet G-M, Deleys R, and Burke DS: Phylogenetic analysis of gag genes from seventy international HIV-1 isolates provides evidence for multiple genotypes. AIDS 1993;7:769-780.

13. Louwagie J, Delwart EL, Mullins JI, McCutchan FE, Eddy G, and Burke DS: Genetic analysis of HIV-1 isolates from Brazil reveals 
the presence of two distinct genotypes. AIDS Res Hum Retroviruses 1994;10:561-567.

14. Chaisson RE, Stanton DL, Gallant JE, Rucker S, Bartlett JG, and Moore RD: Impact of the 1993 revision of the AIDS case definition on the prevalence of AIDS in a clinical setting. AIDS 1993;7:857-862.

15. World Health Organization: Acquired immunodeficiency syndrome (AIDS): Proposed WHO criteria for interpreting results from Western blot assays for HIV-1, HIV-2, and HTLV-I/HTLVII. Wkly Epidemiol Rec 1990;65:281-283.

16. Myers G, Korber B, Wain-Hobson S, Smith RF, and Pavlakis GN: Human Retroviruses and AIDS. Los Alamos National Laboratory, Los Alamos, New Mexico, 1993.

17. Janssens W, Heyndrickx L, Van de Peer Y, Bouckaert A, Fransen K, Motte J, Gershy-Damet G-M, Peeters M, Piot P, and van der Groen G: Molecular phylogeny of part of the env-gene of human immunodeficiency virus type 1 strains isolated in Côte d'Ivoire. AIDS 1994;8:21-26.

18. Barré-Sinoussi F, Chermann JC, Rey F, Nugeyre MT, Chamaret S, Gruest J, Dauguet C, Axler-Blin C, Brun-Vezinet F, Rouzioux C, Rozenaum W, and Montagnier L: Isolation of a T-lymphotropic retrovirus from a patient at risk group for acquired immunodeficiency (AIDS). Science 1983;220:868-871.

19. Sambrook J, Fristch EF, and Maniatis T: Molecular Cloning: A Laboratory Manual. Cold Spring Harbor Laboratory Press, Cold Spring Harbor, New York, 1989.

20. Hultman T, Stahl S, Hornes E, and Uhlen M: Direct solid phase sequencing of genomic and plasmid DNA using magnetic beads as solid support. Nucleic Acids Res 1989;17:4937-4946.

21. Jukes TH and Cantor CR: Evolution of protein molecules. In Mammalian Protein Metabolism. Munro HN (ed.). Academic Press, New York, 1969, pp. 21-132.

22. Van de Peer Y, Neefs J, and De Wachter R: Small ribosomal subunit RNA sequences, evolutionary relationships among different life forms, and mitochondrial origins. J Mol Evol 1990;30:463-476.

23. Saitou $\mathbf{N}$ and Nei $M$ : The neighbour-joining method: $A$ new method for reconstructing phylogenetic trees. Mol Biol Evol 1987;4:406-425.

24. Sourdis $J$ and Nei M: Relative efficiencies of the maximum parsimony and distance-matrix methods in obtaining the correct phylogenetic tree. Mol Biol Evol 1988;5:298-311.

25. Saitou $\mathbf{N}$ and Imanishi $\mathrm{T}$ : Relative efficiencies of the FitchMargoliash, maximum-parsimony, maximum-likelihood, mini- mum-evolution, and neighbour-joining methods of phylogenetic tree construction in obtaining the correct tree. Mol Biol Evol 1989;6:514-525.

26. Van de Peer Y and De Wachter R: TREECON: A software package for the construction and drawing of evolutionary trees. Comput Applic Biosci 1993;9:177-182.

27. McCutchan FE, Hegerich PA, Brennan TP, Phanuphac P, Singharaj P, Jugsudee A, Berman PW, Gray AM, Fowler AK, and Burke DS: Genetic variants of HIV-1 in Thailand. AIDS Res Hum Retroviruses 1994 (in press).

28. Ou CY, Ciesielski CA, Myers G, Bandea CI, Luo CC, Korber BT, Mullins JI, Schochteman G, Berklelman RL, Economou AN, et al.: Molecular epidemiology of HIV transmission in a dental practice. Science 1992;256:1165-1171.

29. Kuiken CL, Zwart G, Baan E, Coutinho RA, van den Hoek JA, and Goudsmit J: Increasing antigenic and genetic diversity of the V3 variable domain of the human immunodeficiency virus envelope protein in the course of the AIDS epidemic. Proc Natl Acad Sci USA 1993;90:9061-9065.

30. Korber B, Wolinsky S, Haynes B, Kunstman K, Levy R, Furtado M, Otto P, and Myers G: HIV-1 intrapatient sequence diversity in the immunogenic V3 region. AIDS Res Hum Retroviruses 1992;8:1461-1465.

31. Gomez Carrillo MG, Piccardo C, and Libonatti O: Analisis molecular del principal epitope de neutralizacion ("V3 lopp") del virus de la immunodeficiencia humano tipo 1 de la Argentina. Rev Arg Microbiol 1992;24:91-101.

32. Wilmot CM and Thornton JM: Analysis and prediction of the different types of B-turn in proteins. J Mol Biol 1988;203:221-232.

33. Javaherian K, Langlois AJ, McDanal C, Ross KL, Eckler LI, Jellis CL, Profy AT, Rusche JR, Bolognesi DP, Putney SD, et al.: Principal neutralizing domain of the human immunodeficiency virus type 1 envelope protein. Proc Natl Acad Sci USA 1989;86:6768-6772.
Address reprint requests to: Wouter Janssens

Division of Microbiology

Department of Infection and Immunity Institute of Tropical Medicine Nationalestraat 155 2000 Antwerp, Belgium 